\title{
PROPOSTA DE UM INDICADOR DE ROTATIVIDADE DOCENTE NA EDUCACÃO BÁSICA
}

\author{
Maíra Gallotti Frantz \\ Thiago Alves ${ }^{\text {II }}$ \\ I Universidade de São Paulo (USP), São Paulo (SP), Brasil; mairagallotti@gmail.com \\ II Universidade Federal de Goiás (UFG), Goiânia (GO), Brasil; thiagoalves.edu@gmail.com
}

\section{Resumo}

Este artigo propõe uma medida para a rotatividade docente na educação básica tomando a escola como unidade de análise. Foram consideradas variáveis potencialmente explicativas como dependência administrativa, etapa/modalidade de ensino e vínculo empregatício. A parte empírica foi realizada com base nos microdados do Censo Escolar de 2016 e 2017 (Inep, 2017, 2018) e focalizou o município de Curitiba-PR. Os resultados sugerem que a rotatividade em 2017 foi de 34,4\%. No nível das escolas, a taxa mediana foi $55,4 \%$ na rede estadual, $22,2 \%$ na rede municipal e $16,5 \%$ na rede federal. Em relação às escolas privadas, a maior mediana deu-se entre as instituições conveniadas (33,3\%). Os resultados reiteram o fenômeno como questão relevante para a agenda das políticas educacionais e da gestão das redes públicas de ensino.

MOBILIDADE DOS PROFESSORES • INDICADORES EDUCACIONAIS • POLÍTICA EDUCACIONAL • EDUCAÇÃO BÁSICA

\section{PROPOSAL FOR A TEACHER TURNOVER INDICATOR IN BASIC EDUCATION}

\section{Abstract}

This paper proposes a measure for teacher turnover in basic education, considering the school as an analysis unit. Potentially explanatory variables such as type of providers (public and private institutions, level of education, and employment relationship were considered. The empirical part was based on microdata from the 2016 and 2017 School Census (Inep, 2017, 2018) and focused on the municipality of Curitiba-PR. The results suggest that turnover in 2017 was $34.4 \%$. At the school level, the median rate was $55.4 \%$ in the state government system, $22.2 \%$ in the local government system, and $16.5 \%$ in the federal network. Regarding private schools, the highest median was among the government-dependent institutions (33.3\%). The results reiterate the phenomenon as a relevant issue for the educational policy agenda and the management of public school systems. 


\section{PROPUESTA DE UN INDICADOR DE ROTACIÓN DOCENTE EN EDUCACIÓN BÁSICA}

\section{Resumen}

Este artículo propone una medida para la rotación docente en la educación básica, tomando la escuela como una unidad de análisis. Fueron consideradas variables potencialmente explicativas como dependencia administrativa, etapa/modalidad de enseñanza y vínculo laboral. La parte empírica se realizó sobre la base de los microdatos del Censo Escolar 2016 y 2017 (Inep, 2017, 2018) y se centró en el municipio de Curitiba-PR. Los resultados sugieren que la rotación en 2017 fue del 34,4\%. A nivel escolar, la tasa media fue de $55.4 \%$ en la red estatal, $22.2 \%$ en la red municipal y $16.5 \%$ en la red federal. Entre las escuelas privadas, la mediana más alta se dio entre las instituciones asociadas $(33,3 \%)$. Los resultados reiteran el fenómeno como una cuestión relevante para la agenda de las políticas educativas y de la gestión de las redes públicas de enseñanza.

MOVILIDAD DEL PROFESOR • INDICADORES EDUCATIVOS • POLÍTICA EDUCATIVA • EDUCACIÓN BÁSICA

\section{PROPOSITION D'UN INDICATEUR DE ROTATION DES ENSEIGNANTS DANS L'ÉDUCATION DE BASE}

\section{Résumé}

Cet article propose un indicateur de la rotation des enseignants dans l'éducation de base en utilisant l'école comme unité d'analyse. Des variables potentiellement explicatives ont été prises en compte, tels que le réseau d'appartenance administrative, le niveau ou les modalités d'enseignement et le type de contrat de travail. La part empirique repose sur des microdonnées du Recensement Scolaire de 2016 et 2017 (Inep, 2017, 2018) pour la commune de Curitiba-PR. Les résultats suggèrent qu'en 2017 la rotation du personnel enseignant était de 34,4\%. Le taux médian de rotation du personnel était de 55,4\% pour les écoles appartenant au réseau de l'État du Parana de 22,2\% pour les écoles municipales et de $16,5 \%$ pour les écoles du réseau féderal. Dans les écoles privées, le taux moyen le plus élevé concernait les établissements sous contrat (33,3\%). Les résultats confirment l'importance du phénomène pour l'élaboration de l'agenda des politiques éducatives et la gestion des systèmes d'enseignement public.

MOBILITÉ DES ENSEIGNANTS • INDICATEURS ÉDUCATIFS • POLITIQUE ÉDUCATIVE • ÉDUCATION DE BASE 
PRESENTE ARTIGO PROPÕE UM INDICADOR PARA MEDIR E COMPREENDER O FENÔMENO DA rotatividade docente nas escolas de educação básica. Para tanto, concebe a rotatividade docente como a saída do professor de uma escola, seja em razão de migração para outra escola, seja por aposentadoria ou, ainda, por abandono da profissão (Ingersoll, 2001).

A relevância da sua mensuração dá-se por considerar que esse fenômeno recai, com elevado grau de incidência (Frantz, 2018; Pereira \& Oliveira, 2016), sobre um trabalho que requer altos níveis de continuidade e de interação social (Tardif \& Lessard, 2014) para atingir os fins relacionados a uma esfera política, dado seu caráter de agente social premente no processo civilizatório (Fanfani, 2005).

A rotatividade profissional é um fenômeno comum nas organizações públicas e privadas das diversas áreas da economia e, até certo nível, sua ocorrência é esperada ou, em alguns casos, até mesmo desejada. Todavia, as organizações procuram mensurar (e mesmo prevenir, monitorar e mitigar) sua incidência por entender que, em elevados níveis, pode comprometer o alcance dos objetivos organizacionais e gerar elevados gastos com demissão, recrutamento, seleção e desenvolvimento de novos membros de equipe.

No setor público, a relevância da rotatividade como objeto de estudo põe-se, sobretudo, por considerar que o Estado, constituído por um sistema complexo e abstrato pautado em normas e regras estatuídas em texto constitucional, despersonaliza o poder. Evidencia-se, assim, a coisa pública, demandando um corpo funcional que atue em decorrência do reconhecimento dessa dominação racional-burocrática (Weber, 1994) e, ainda, de uma moral profissional específica (Supiot, 1995), com vistas à efetivação de serviços públicos que materializem direitos positivados no ordenamento jurídico. Desse modo, enquanto, nas organizações do setor privado, a rotatividade profissional é observada com vistas à redução de custos e ao desenvolvimento de estratégias de fixação e de recrutamento de trabalhadores que culminem na otimização da produtividade e maximização de lucros, no âmbito público, a referida rotatividade profissional enseja, para além dos custos, o rompimento da prestação de serviços sociais que operacionalizam a própria função do Estado. No entanto, a literatura sobre o tema permite concluir que seu lugar no âmbito da administração pública brasileira revela-se ainda pouco recorrente e tem maior frequência na área da saúde (Campos \& Malik, 2008; Diógenes et al., 2016; Linhares, 2014; Medeiros et al., 2010; Sancho et al., 2011; Torres, 2015).

No contexto escolar, a incidência do fenômeno da rotatividade profissional imbrica-se à função social da educação e ao asseguramento do direito constitucionalmente estatuído, vinculado ao compromisso com a efetivação de um processo amplo, sistemático e intencional de humanização dos sujeitos através da apropriação de determinados saberes e elementos da cultura geral, transpostos para a cultura escolar (Silva, 2011). Esse processo complexo dá-se à luz de um projeto educativo comum, forjado por intensa correlação de forças sociais, o qual carrega uma dimensão político-pedagógica, tendo como premissa legal a mais ampla participação dos sujeitos ${ }^{1}$ (Constituição da República Federativa do Brasil, 1988; Lei n. 9.394, de 1996). Demanda, assim, esforços coletivos e contínuos para a sua construção e consecução.

Destarte, parece oportuno pensar que a ausência de continuidade, imputada por elevada incidência de rotatividade do quadro docente, produz interferências não apenas sobre as finalidades da educação escolar, mas também diretamente sobre a função do próprio trabalho docente.

1 Conforme estabelece o Art. 206, inciso VI da Constituição Federal (CF) e o Art. 3, inciso VIII da Lei de Diretrizes e Bases da Educação Nacional (LDB). 
Contudo, apesar dos esforços expressos em estudos internacionais para a compreensão do fenômeno da rotatividade docente - tais como os de Ingersoll (2001), Johnson et al. (2005) e Grissom (2011) -, no cenário educacional brasileiro ele é ainda pouco pesquisado. Essa afirmação sustenta-se na identificação, em processo de levantamento bibliográfico, de reduzido número de estudos que o tomam como elemento central de análise. Outro ponto que esse levantamento permite observar é que, em geral, a exemplo da constatação de Ingersoll (2001) para o contexto estadunidense, os esforços científicos para compreensão da rotatividade têm estabelecido o professor como unidade de análise. O conjunto de pesquisas nacionais evidencia, como referências explicativas, a predominância de características individuais, adjacentes ao próprio trabalhador ou à sua relação direta e individual com o trabalho.

No presente estudo, embora se reconheça que a decisão que culmina na rotatividade parte de cada docente, entende-se que olhar para o fenômeno de modo isolado, restrito ao trabalhador e suas características pessoais, impede observá-lo à luz da correlação de forças organizacionais que concorre para a sua produção. Por tal razão, o percurso metodológico ora apresentado toma a escola como principal unidade de análise.

As questões subjacentes ao artigo são: qual é o nível de rotatividade docente nas escolas de educação básica? Qual é a magnitude desse fenômeno entre as escolas das redes públicas e privada? Quais são os possíveis fatores explicativos para sua incidência?

O delineamento da pesquisa considera todas as escolas em funcionamento no município de Curitiba-PR no ano 2016 e calcula a rotatividade docente ocorrida em 2017. De acordo com o Censo Escolar realizado pelo Instituto Nacional de Estudos e Pesquisas Educacionais Anísio Teixeira (Inep), em 2016, o município contava com 23,6 mil professores atuando nas salas de aula de 1.053 escolas da educação básica. A rede municipal empregava 9,7 mil docentes (41,2\%) em 390 unidades de ensino, que ofertavam 130,4 mil matrículas no município (30,7\%).

A análise foi realizada em duas etapas. Na primeira, foi calculado o indicador de rotatividade para todos os docentes e todas as escolas. Os resultados das dependências administrativas públicas e tipo de mantenedor privado foram comparados. Na segunda, foi selecionada a rede municipal de ensino, com o intento de medir a incidência do fenômeno em um contexto que, supostamente, teria maior similaridade no que se refere às condições estruturantes do trabalho docente. É importante ressaltar ainda que tal rede aprovou a Lei Municipal n. 10.190 (2001), que estabeleceu uma política de incentivo à permanência em escolas que apresentavam alta rotatividade do quadro docente; a principal estratégia da referida política, a partir de $2003,{ }^{2}$ foi o pagamento de gratificação pecuniária aos docentes sobre o vencimento inicial da carreira.

A estrutura deste artigo compõe-se, primeiramente, da apresentação do referencial teórico-empírico que sustentou as decisões metodológicas e orientou as análises dos resultados. Em seguida, o texto explicita o percurso metodológico com um detalhamento em cinco etapas. Subsequentemente, são apresentados os resultados e a discussão da aplicação do indicador proposto. Por fim, expõem-se as considerações finais.

\section{Referencial teórico-empírico}

Em termos conceituais, segundo Ingersoll (2001), a rotatividade docente vincula-se à saída dos professores de seus postos de trabalho, podendo dar-se em caráter voluntário ou involuntário, e, via de regra, pressupõe substituição. No entanto, o autor ressalta que pesquisas frequentes sobre a rotatividade docente, oriundas do contexto internacional, têm-na observado prioritariamente sob a dimensão da 
saída da profissão (attrition), seja por abandono ou por aposentadoria. Assim, tais estudos ignoram os dados referentes à saída do professor de uma escola para entrada em outra, já que esse movimento, denominado migração (migration), não afeta o quadro sistêmico de ocupações. Essa dimensão é também citada nos estudos nacionais de Torres (2015), que a situa como uma condição menos importante, denotando sua frequência mais comum nas produções do serviço público e do trabalho docente.

Neste artigo, assume-se o conceito de rotatividade docente apresentado por Ingersoll (2001) como referência. Para o autor, rotatividade consiste na saída do docente de uma escola, o que engloba saída da profissão, aposentadoria e migração. A escolha dessa definição está baseada em dois pressupostos. O primeiro diz respeito à função social da escola e à especificidade do trabalho docente. Diante do exposto, é possível inferir que a incidência de graus elevados de rotatividade, sejam provenientes da saída por abandono da profissão, aposentadoria ou por migração de uma escola para outra, produz efeitos similares sobre a operacionalização da sua função social e das relações sociais de trabalho em seu interior. Portanto, não seria adequado ignorar qualquer uma das dimensões que a abarcam.

O segundo pressuposto alude ao objetivo da pesquisa, relacionado à compreensão do fenômeno no contexto das escolas de educação básica. Distingue-se, portanto, de estudos que objetivam produzir um balanço geral e sistêmico das ocupações, a exemplo daqueles provenientes do Ministério do Trabalho e Emprego (MTE, 2013), e em parceria com o Departamento Intersindical de Estatística e Estudos Socioeconômicos (Dieese, 2014a, 2014b), para os quais importa a rotatividade na dimensão da saída, excluída a análise sobre migração.

Outro fator importante remete à suposição de substituição ante a saída, já que se entende que a rotatividade é prejudicial não apenas pelas saídas e alternâncias no quadro docente de uma escola, mas também pela brecha que abre para a existência de vagas não cobertas. Essa compreensão, tal como apresentada na Tabela 1 (constante na seção reservada aos aspectos metodológicos deste artigo) foi decisiva para o processo de testagem e proposição de um indicador.

No que tange à rotatividade docente, Ingersoll (2001) assinala a prevalência da dimensão individual, explicitando um corpo teórico de magnitude, que busca fatores explicativos a partir de características do próprio professor, a fim de categorizar um perfil com maior predisposição a deixar a profissão. Segundo o autor, embora pesquisas dessa natureza tenham sido importantes para sua compreensão, a omissão de outros fatores explicativos, relacionados às características das escolas e das condições organizacionais, tem sido prejudicialmente ignorada, levando à exploração do fenômeno da rotatividade docente como algo isolado do seu contexto de origem, o que acaba por conformar a escola como vítima de tendências demográficas e ignorar a possibilidade de uma concentração elevada de rotatividade em tipos particulares de escola. Para o autor, a identificação de fontes organizacionais de alta rotatividade permitiria observar não apenas problemas de pessoal, mas também e especialmente fragilidades na consecução das finalidades da escola e em termos de coesão da equipe.

Interessante observar que estudos sobre história da profissão docente atribuem à mobilidade dos professores, através de sucessivas transferências entre escolas, uma marca da própria constituição da carreira docente (Vicentini \& Lugli, 2009). Explicam que, ao final do século XIX, os professores, em especial em São Paulo, escolhiam as escolas onde lecionariam com base na pontuação acumulada na carreira, de acordo com a valoração creditada à escola de origem. Essa pontuação estaria associada à distância da escola em relação aos centros urbanos. Tal processo acabava por produzir um grau elevado de rotatividade docente nas escolas mais isoladas. Além disso, produziria uma hierarquização entre as escolas e, portanto, elevaria seu grau de prestígio social e de seus professores. Se cotejada tal conclusão aos achados de pesquisa no serviço público em Campos e Malik (2008), é possível observar que o prestígio da organização, ainda hoje, apresenta uma relação com baixas taxas de rotatividade profissional.

Segundo Pereira e Oliveira (2016), os diretores escolares apontam que a rotatividade docente consiste em um dos problemas atuais salientes a serem enfrentados em 32,6\% das escolas públicas 
brasileiras. Pereira (2017) afirma ainda que a sua incidência é um fator associado às condições de trabalho docente.

Contudo, no cenário educacional brasileiro, o assunto é ainda pouco explorado. Tal afirmação assenta-se em um levantamento documental realizado, por meios digitais, em repositórios de universidades brasileiras e por meio de consulta ao acervo da Biblioteca Digital Brasileira de Teses e Dissertações (BDTD), à base de periódicos científicos Scientific Eletronic Library Online (SciELO), ao Sistema de Información Científica Redalyc (Red de Revistas Científicas de América Latina e El Caribe, España e Portugal), à Scientific Periodicals Eletronic Library (Spell) e ao recurso Google Acadêmico, tomando como referência descritores específicos (rotatividade profissional, rotatividade docente, turnover, teacher turnover, migration, attrition, abandono da profissão e evasão docente). Um dos critérios assumidos no referido levantamento documental foi a seleção de pesquisas realizadas no Brasil que evidenciassem centralidade de estudo sobre o fenômeno da rotatividade, posto que muitas ocorrências o abordavam de modo periférico. As pesquisas selecionadas foram produzidas sob a ótica de três áreas do conhecimento: educação (Azevedo, 2012; Cunha, 2015; Pereira \& Oliveira, 2016; Silva, 2007); administração (Siqueira \& Alves, 2016); e economia (Duarte, 2009; Kasmirski, 2012). Tal classificação deu-se com base na ideia de que a gênese das pesquisas imprime marcas próprias ao fenômeno investigado e, igualmente, indica sua relevância em diferentes áreas.

Desse modo, observou-se que os quatro estudos realizados no âmbito da educação, mesmo recorrendo a teorias externas à área, resguardam articulações, em graus distintos, destas com referenciais teóricos e empíricos que marcam a singularidade do trabalho docente e da função social da escola.

Já os estudos oriundos da economia e da administração discorrem sobre o tema partindo, essencialmente, de referenciais teóricos próprios das teorias organizacionais e do comportamento organizacional, concebendo a escola como uma organização passível de generalização. Nesse sentido, não captam delineamentos próprios, tanto em relação à função social da escola quanto em relação à natureza singular, imaterial e interativa do trabalho docente (Tardif \& Lessard, 2014). É preciso considerar que mudanças frequentes no quadro de uma escola implicam abdicar do caráter coletivo, processual e contínuo que a formação humana intencional e planejada requer. Destaca-se ainda o reconhecimento de que a consecução de seus fins demanda a manutenção de vínculo do professor, em longo prazo, com o estudante, de modo a assegurar a adesão e motivação deste para a participação cotidiana em um trabalho imaterial e a conversão da obrigação social de estudar em interesse subjetivo. Além disso, há que considerar que a função social da escola não se restringe às concepções, aspirações e decisões de foro individual (e, por vezes, antagônicas) de cada trabalhador; ao contrário, tal função visa, sobretudo, a articulá-las, por meio de um processo de busca constante de consensos possíveis, com vistas à efetivação de um compromisso coletivo e socialmente assumido de materialização de um projeto educativo e social comum.

Em termos conceituais, ainda que partindo de vertentes distintas, as sete pesquisas são unânimes em definir rotatividade docente em âmbito global.

Quanto às escolhas metodológicas, um estudo mostra-se essencialmente qualitativo (Azevedo, 2012) e os demais expressam técnicas quantitativas de análise. Dentre as pesquisas que utilizam métodos quantitativos, no que se refere à unidade de análise para definição de variáveis explicativas, uma analisa a rotatividade essencialmente sob a ótica da organização, duas privilegiam a dimensão individual dos trabalhadores, duas abarcam ambas as dimensões e uma olha o fenômeno sob a ótica da turma, articulando-a à escola e ao município. Já a pesquisa que apresenta unicamente métodos qualitativos de análise associa a incidência do fenômeno a alguns fatores relacionados à organização e ao trabalhador.

Tal conjunto de pesquisas reitera o pressuposto de que altos graus de rotatividade podem gerar rupturas no funcionamento da instituição escolar e no trabalho docente. Concedem, ainda, robustez à decisão de trabalhar com o conceito global de rotatividade docente. 
A análise desses estudos, além de orientar parte da tomada de decisão da presente pesquisa, parece referendar a necessidade de um percurso que situe as singularidades da rotatividade docente na área educacional no contex to brasileiro e, quando oportuno, na esfera pública. Nesse ponto, destaca-se a importância de reconhecer as marcas distintivas da esfera pública em relação à esfera privada sobre as finalidades e as relações de trabalho, as quais, regulamentadas por estatuto próprio e não por celebração de contrato, ao contrário do intento de geração de lucro, implicam relações complexas, tanto do ponto de vista da remuneração e do tempo destinado ao trabalho quanto das relações de poder, subordinadas ao interesse público para asseguramento de direitos que não podem ser violados ou concebidos como privilégios (Supiot, 1995).

Ante a prevalência de esforços, nas pesquisas levantadas, para observar aspectos individuais do professor como fatores associados à incidência da rotatividade docente - e, portanto, do desenho de um perfil propenso a ela -, é possível reiterar a relevância de pesquisas que ampliem a sua observação, na dimensão da escola.

Por fim, os esforços trilhados para mensuração da rotatividade docente conferem uma "janela" de oportunidades para a sofisticação de indicadores correlatos.

\section{Aspectos metodológicos}

O percurso de elaboração da medida de rotatividade docente no nível de escola ocorreu em cinco etapas. A primeira deu-se com a definição do conceito de rotatividade docente que, resguardada a coerência em relação aos pressupostos teóricos, orientou os procedimentos metodológicos subsequentes.

A segunda etapa consistiu no levantamento de métodos (estratégias e fórmulas) para o cálculo do indicador. Nesse ponto, dado o escasso aporte empírico disponível, optou-se por recorrer também às pesquisas que analisaram rotatividade em outras categorias profissionais no setor público. Assim, o lastro teórico e empírico levantado - expresso nos estudos de Campos e Malik (2008), Medeiros et al. (2010), Sancho et al. (2011), Paranaíba (2014), Torres (2015) e Diógenes et al. (2016) - somou-se ao repertório de pesquisas sobre a rotatividade docente, relativo às produções científicas de Pereira e Oliveira (2016), Cunha (2015), Kasmirski (2012) e Duarte (2009). Igualmente, foram consideradas as estratégias de medição utilizadas pelo MTE e pelo Instituto Brasileiro de Geografia e Estatística (IBGE) na Pesquisa Industrial Mensal de Emprego e Salário (Pimes), em virtude da robustez dos esforços para a visibilidade do fenômeno em âmbito nacional. Por fim, foi também considerada a forma de cálculo de Nomura e Gaidzinski (2005) referente à área da saúde.

\section{Fórmulas para medir a rotatividade docente}

Após análises desses estudos, na terceira etapa, foram selecionadas cinco fórmulas para testagem dos resultados a partir de situações hipotéticas de movimentação docente nas escolas. Com o teste empírico verificou-se que, apesar das similaridades, nenhuma das fórmulas gerou resultados que captassem, com precisão, o conceito de rotatividade docente adotado neste estudo. Por isso, foi proposta uma nova fórmula. O Quadro 1 apresenta as seis fórmulas em comparação. 
QUADRO 1

FÓRMULAS SELECIONADAS PARA CÁLCULO DA ROTATIVIDADE DOCENTE ${ }^{1}$

\begin{tabular}{|c|c|c|c|c|c|}
\hline $\begin{array}{l}\text { PEREIRA E OLIVEIRA } \\
(2016)\end{array}$ & $\begin{array}{l}\text { CAMPOS E MALIK } \\
\text { (2008) }\end{array}$ & $\begin{array}{c}\text { NOMURA E } \\
\text { GAIDZINSKI (2005) }\end{array}$ & MTE (2013) & IBGE/Pimes & Fórmula proposta \\
\hline $\begin{array}{l}\frac{\frac{E+S}{2}}{\frac{N(i-1)+N(i)}{2}} \\
\text { Onde: } \\
\text { * } \mathrm{E}=\text { número } \\
\text { de docentes } \\
\text { que entraram } \\
\text { para a unidade } \\
\text { educacional } \\
\text { no ano (i) em } \\
\text { comparação ao } \\
\text { período anterior } \\
\text { ( } \mathrm{i}-1) ; \\
\text { * } \mathrm{S}=\text { número de } \\
\text { docentes que } \\
\text { saíram da unidade } \\
\text { educacional } \\
\text { no ano (i) em } \\
\text { comparação ao } \\
\text { período anterior } \\
(\mathrm{i}-1) ; \\
\text { * } \mathrm{N}(\mathrm{i}-1)=\text { número } \\
\text { total de docentes } \\
\text { da unidade } \\
\text { educacional no } \\
\text { período anterior; } \\
\text { * } \mathrm{N}(\mathrm{i})=\text { número } \\
\text { total de docentes } \\
\text { da unidade } \\
\text { educacional } \\
\text { no período em } \\
\text { análise. }\end{array}$ & 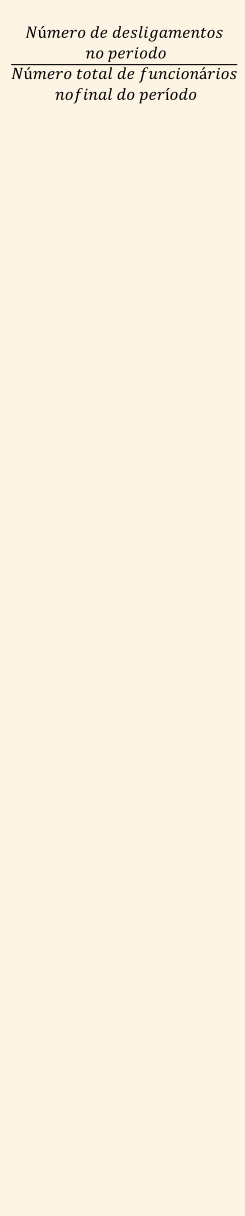 & $\begin{array}{l}\frac{D}{(M i+M f)} \\
2 \\
\text { Onde: } \\
\text { * } \mathrm{D}=\text { número de } \\
\text { desligamentos no } \\
\text { período analisado; } \\
\text { * Mi = número de } \\
\text { trabalhadores no } \\
\text { início do período } \\
\text { considerado; } \\
\text { * Mf = número de } \\
\text { trabalhadores no } \\
\text { final do período } \\
\text { considerado. }\end{array}$ & $\begin{array}{c}\text { Min (ADMt, DESt }) \\
\text { Tamanho médio da } \\
\text { força de trabalho } \\
\text { no período } \\
\text { Onde: } \\
\text { * min(ADMt, } \\
\text { DESt) = menor } \\
\text { valor encontrado } \\
\text { entre admissões } \\
\text { e desligamentos } \\
\text { no período de } \\
\text { referência da } \\
\text { pesquisa. } \\
\text { * estoque médio de } \\
\text { trabalhadores entre } \\
\text { o início e o final do } \\
\text { exercício. }\end{array}$ & $\begin{array}{l}\frac{\text { Min }(A D M t, D E S t)}{P O A(t-1)} \\
\text { Onde: } \\
\text { * min(ADMt, } \\
\text { DESt) = menor } \\
\text { valor encontrado } \\
\text { entre admissões } \\
\text { e desligamentos } \\
\text { no período de } \\
\text { referência da } \\
\text { pesquisa; } \\
\text { * POA (t - 1) = } \\
\text { total de pessoas } \\
\text { assalariadas } \\
\text { no período } \\
\text { imediatamente } \\
\text { anterior. }\end{array}$ & $\begin{array}{c}\frac{S}{N(i-1)} \\
\text { Onde: } \\
\text { * } \mathrm{S}=\text { quantidade } \\
\text { total de docentes } \\
\text { que saíram da } \\
\text { escola, obtida } \\
\text { pela comparação } \\
\text { entre o total de } \\
\text { docentes no ano } \\
\text { analisado (i) e no } \\
\text { ano imediatamente } \\
\text { anterior (i }-1) ; \\
\text { * } \mathrm{N}(\mathrm{i}-1)= \\
\text { quantidade total } \\
\text { de docentes no ano } \\
\text { imediatamente } \\
\text { anterior ao } \\
\text { analisado (i). }\end{array}$ \\
\hline
\end{tabular}

Fonte: Elaboração dos autores.

Nota: (1) As notações matemáticas das fórmulas estão apresentadas conforme os trabalhos originais.

A fórmula proposta neste estudo partiu do entendimento de que o indicador de rotatividade docente deve captar somente o movimento de saída. Desse modo, considera o número de saídas no ano de referência da análise em relação ao número total de docentes do ano-base de comparação (ano anterior). A taxa é calculada por meio de uma razão entre o número de docentes que, no ano de referência, saíram das escolas que trabalhavam no ano anterior. $\mathrm{O}$ resultado é multiplicado por $100 \mathrm{a}$ fim de expressá-lo em forma de taxa percentual.

\section{Teste de validade das fórmulas}

A etapa quatro consistiu na realização de testes de validade. O objetivo do procedimento foi verificar qual fórmula apresentava resultado numérico mais fidedigno ao conceito de rotatividade adotado. ${ }^{3}$ Nessa etapa, duas preocupações foram prementes. Uma era não computar a quantidade

3 Segundo Jannuzzi (2005), "validade" é um atributo fundamental para indicadores sociais, pois expressa a proximidade da medida numérica do conceito abstrato que Ihe deu origem; ou seja, tem bom nível de validade o indicador que "mede" adequadamente o construto que pretende descrever. 
de entradas na produção do indicador, em face do conceito de rotatividade docente assumido e da possibilidade de, ao incorporar dados de entrada na forma de cálculo, gerar informações que atribuíssem rotatividade docente a situações em que houve apenas entrada (e ausência de saída). A outra foi construir um indicador que não reduzisse as taxas de rotatividade frente à não substituição do quadro docente. Para isso, foram elaborados 14 cenários da realidade escolar para as seguintes situações de saídas e entradas de docentes:

1. saidas e entradas em quantidades equivalentes, imprimindo rotatividade sem alterar o quadro docente total da escola;

2. saídas em número inferior à quantidade de entradas, gerando rotatividade em um cenário de ampliação do quadro docente. Nesta condição, gerou-se também, para efeitos de análise, uma situação em que não há saídas, apenas entradas;

3. saidas em número superior à quantidade de entradas, explicitando um cenário em que a rotatividade é acompanhada da não reposição das vagas existentes, o que gera um déficit no quadro docente geral da escola.

Os resultados dessa testagem estão na Tabela 1.

\section{TABELA 1}

TAXAS DE ROTATIVIDADE DOCENTE EM SITUAÇÕES HIPOTÉTICAS POR DIFERENTES FÓRMULAS

\begin{tabular}{|c|c|c|c|c|c|c|c|c|c|c|c|}
\hline \multirow[b]{2}{*}{ 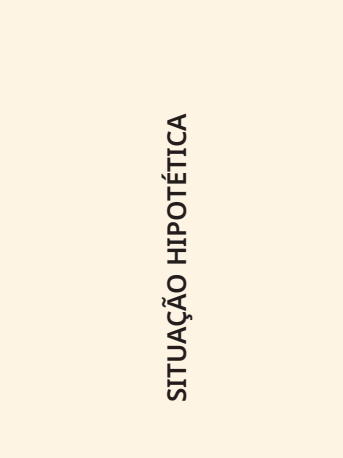 } & \multirow[b]{2}{*}{ 号 } & \multirow[b]{2}{*}{ 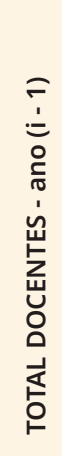 } & \multirow[b]{2}{*}{ 率 } & \multirow[b]{2}{*}{ 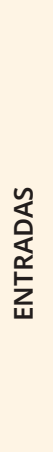 } & \multirow[b]{2}{*}{ 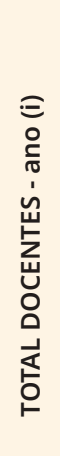 } & \multicolumn{6}{|c|}{ TAXAS DE ROTATIVIDADE DOCENTE (\%) } \\
\hline & & & & & & 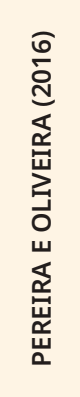 & 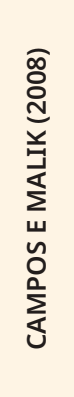 & 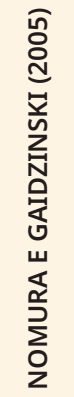 & 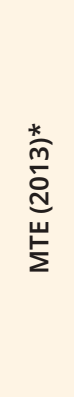 & 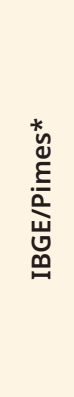 & 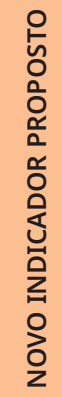 \\
\hline \multirow{5}{*}{$\begin{array}{l}\text { 1. Saídas e entradas em } \\
\text { quantidades equivalentes }\end{array}$} & A & 60 & 5 & 5 & 60 & 8,3 & 8,3 & 8,3 & 8,3 & 8,3 & 8,3 \\
\hline & B & 25 & 2 & 2 & 25 & 8,0 & 8,0 & 8,0 & 8,0 & 8,0 & 8,0 \\
\hline & C & 30 & 0 & 0 & 30 & 0,0 & 0,0 & 0,0 & 0,0 & 0,0 & 0,0 \\
\hline & D & 40 & 4 & 4 & 40 & 10,0 & 10,0 & 10,0 & 10,0 & 10,0 & 10,0 \\
\hline & $\mathrm{E}$ & 50 & 10 & 10 & 50 & 20,0 & 20,0 & 20,0 & 20,0 & 20,0 & 20,0 \\
\hline \multirow{5}{*}{$\begin{array}{l}\text { 2. Saídas em número } \\
\text { inferior à quantidade de } \\
\text { entradas }\end{array}$} & $\mathrm{F}$ & 60 & 5 & 13 & 68 & 14,1 & 7,4 & 7,8 & 7,8 & 8,3 & 8,3 \\
\hline & G & 25 & 2 & 7 & 30 & 16,4 & 6,7 & 7,3 & 7,3 & 8,0 & 8,0 \\
\hline & $\mathrm{H}$ & 30 & 0 & 5 & 35 & 7,7 & 0,0 & 0,0 & 0,0 & 0,0 & 0,0 \\
\hline & I & 40 & 4 & 8 & 44 & 14,3 & 9,1 & 9,5 & 9,5 & 10,0 & 10,0 \\
\hline & J & 50 & 10 & 12 & 52 & 21,6 & 19,2 & 19,6 & 19,6 & 20,0 & 20,0 \\
\hline \multirow{4}{*}{$\begin{array}{l}\text { 3. Saídas em número } \\
\text { superior à quantidade de } \\
\text { entradas }\end{array}$} & L & 60 & 5 & 2 & 57 & 6,0 & 8,8 & 8,5 & 3,4 & 3,3 & 8,3 \\
\hline & $M$ & 25 & 2 & 0 & 23 & 4,2 & 8,7 & 8,3 & 0,0 & 0,0 & 8,0 \\
\hline & $\mathrm{N}$ & 40 & 4 & 2 & 38 & 7,7 & 10,5 & 10,3 & 5,1 & 5,0 & 10,0 \\
\hline & $\mathrm{O}$ & 50 & 10 & 3 & 43 & 14,0 & 23,3 & 21,5 & 6,5 & 6,0 & 20,0 \\
\hline
\end{tabular}

Fonte: Elaboração dos autores.

Nota: $\left(^{*}\right)$ O cálculo desses percentuais, quando realizado no contexto do MTE (2013) e do IBGE, é precedido de análises sobre o

indicativo de substituições, a fim de caracterizar o cenário de contração (quando o número de saídas é maior que o de entradas) ou expansão (quando o número de saídas é inferior ao número de entradas). 
Quanto à primeira situação hipotética, com base nos resultados obtidos, é possível inferir que as seis fórmulas utilizadas apresentam taxas iguais em situações de equivalência entre saídas e entradas.

Em relação à segunda situação hipotética, em que a incidência da rotatividade dá-se ante as saídas em quantidade inferior ao número de entradas, destacam-se os resultados do indicador apresentado por Pereira e Oliveira (2016). A sensibilidade da fórmula, a qual capta o incremento dos quadros docentes como rotatividade, eleva consideravelmente as taxas de rotatividade mesmo ante a ausência de saídas (a exemplo da escola “H”). Sabe-se que, em algumas situações, há demanda por aumento no quadro docente por reorganização do trabalho pedagógico, a exemplo do que houve em muitas redes públicas de ensino brasileiras em decorrência da ampliação da carga horária total de hora-atividade, em atenção à Lei n. 11.738 (2008). Por essa fórmula, o aumento de profissionais no quadro, sem saídas dos docentes que ali já estavam, é considerado rotatividade.

Ainda que a entrada de docentes no quadro de uma escola possa aludir à migração, tomada como uma das dimensões do fenômeno, é preciso considerar que sua origem não se dá, exclusivamente, por movimentação interna, podendo decorrer do ingresso na profissão, o que não caracteriza rotatividade docente.

Se comparadas as demais taxas para essa segunda condição, é possível observar que os menores percentuais de rotatividade ante a ampliação do quadro docente evidenciam-se com o indicador proposto por Campos e Malik (2008), seguido daqueles propostos por Nomura e Gaidzinski (2005) e pelo MTE, sucedidos das proposições utilizadas por IBGE/Pimes e daquela construída nesta pesquisa.

No que concerne à proposição de Campos e Malik (2008), ainda que os percentuais para rotatividade ante o incremento sejam os mais baixos no panorama geral, uma comparação do percentual gerado pela mesma fórmula para escolas com iguais quadros docentes no ano i-1 e o mesmo quantitativo de saídas (a exemplo das escolas "A" e " $F$ ") permite observar que essa fórmula acaba por captar, de forma sutil, a ampliação do quadro, gerando graus diferentes de rotatividade para situações equivalentes nos termos supracitados.

$\mathrm{O}$ mesmo ocorre com as demais fórmulas, à exceção daquela proposta nesta pesquisa, que mantém resultados iguais para todas as situações com equivalência relacionada ao total do quadro docente no ano i-1 e à quantidade de saídas, inclusive na terceira condição.

Quanto aos resultados observados na terceira condição, forjada para um cenário em que as saídas são maiores do que as entradas, o que, dessa maneira, gera um déficit no quadro geral da escola, devem-se reconhecer os limites de captação dos indicadores. Se o enfoque da rotatividade está na saída, a substituição das vagas não compõe o recorte para sua mensuração. Ainda assim, é preciso pensar sobre sua sensibilidade mediante saídas sem a substituição pressuposta.

Para essa condição, os resultados dos cálculos utilizados pelo MTE, pelo IBGE/Pimes e por Pereira e Oliveira (2016), se comparados os seus próprios resultados individualmente, evidenciam a redução das taxas de rotatividade ante a não substituição das saídas (a exemplo das escolas "B" e " $M$ ").

Nos casos do MTE e do IBGE/Pimes, o cálculo dos percentuais de rotatividade é precedido da análise dos menores valores entre entradas e saídas a fim de categorizar o cenário, seja em contração ou expansão.

Apesar disso, não sendo desejável que taxas de rotatividade caiam apenas em função da saída sem substituição, o risco de tais resultados para o olhar sobre a rotatividade docente está na possibilidade de eles induzirem interpretações equivocadas da realidade.

Interessante observar que, comparativamente às taxas encontradas em situações similares (total de docentes no ano i-1 e saídas), os resultados expressos nessa condição para Nomura e Gaidzinski (2005) e para Campos e Malik (2008) denotam sutil elevação das taxas ante a não substituição.

Desse processo de levantamento, estudo e testagem concluiu-se que a comparação estabelecida entre os resultados gerados em cada fórmula, individualmente, e os resultados ante as três situações 
desdobradas em 14 cenários, aponta significativa coerência do indicador proposto nesta pesquisa com o conceito de rotatividade adotado. Tal conclusão pauta-se no entendimento de que, mantidas as mesmas quantidades no quadro docente no ano i-1 e nas saídas, o percentual de rotatividade não sofre interferências nem pelo aumento no quadro, nem por seu déficit. Os resultados nas escolas " $\mathrm{D}$ ", "I" e "N" evidenciam essa conclusão. As três possuem 40 docentes. Em todas elas houve a saída de quatro docentes. Aplicando a fórmula proposta neste artigo, as três escolas expressam taxas iguais de rotatividade, uma vez que diferem apenas no quantitativo de entrada. Esse é um aspecto importante a ser observado, atinente à elevação dos graus de "validade", "confiabilidade" e "sensibilidade" dos indicadores sociais (Jannuzzi, 2005). Assim, os resultados desse processo de testagem fundamentaram a escolha do indicador proposto neste artigo para aplicação aos dados empíricos de Curitiba.

\section{Procedimentos para o cálculo da rotatividade docente}

A quinta e última etapa do percurso metodológico consistiu nos procedimentos para aplicação da fórmula proposta na etapa anterior e, finalmente, no cálculo da rotatividade no nível das escolas.

A fonte de dados utilizada foram os microdados do Censo Escolar (Inep, 2017, 2018), especificamente os bancos de dados de docentes e de escolas, dos anos de 2016 e $2017 .{ }^{4} \mathrm{O}$ uso dessa fonte confere ao indicador atributos metodológicos relevantes como confiabilidade, cobertura populacional, periodicidade na sua atualização e factibilidade operacional para sua obtenção.

Também vale ressaltar que neste artigo foram utilizados dados da população dos sujeitos (docentes) e do universo das escolas de Curitiba-PR constantes no Censo Escolar.

Os procedimentos de imputação, tratamento e análise de dados foram realizados com auxílio do software IBM SPSS Statistics. Três filtros foram aplicados ao banco de dados de docentes. O primeiro foi utilizado para restringir o escopo da análise ao município de interesse: Curitiba-PR (variável co município $=4106902$ ). Os dois filtros seguintes foram utilizados para selecionar os docentes segundo as funções que exercem na escola e as turmas que atendem. Foram usadas as categorias convencionalmente elegidas pelo Inep para definição do "docente típico". ${ }^{6}$ Assim, o filtro para a função docente abrangeu as categorias "docente" e "Docente Titular - coordenador de tutoria (de módulo ou disciplina) - EAD" e o filtro para o tipo de turma em que atuam compreendeu as categorias "Não se aplica", "Classe hospitalar", "Unidade de atendimento socioeducativo" e "Unidade prisional".

Em seguida, foi necessário agregar os dados (comando aggregate) pelas variáveis “co_pessoa_ fisica" e "co_entidade" (nessa ordem). Esse procedimento foi necessário porque o banco original tem a "função docente" como unidade de análise (ou seja, o código de um docente pode ser repetido quantas vezes for o número de turmas que o docente leciona). Esse procedimento retira as repetições das turmas e atribui cada docente às escolas em que leciona (podendo ser uma ou mais) e forma um novo banco de dados cuja unidade de análise é o/a docente. Esse procedimento foi realizado separadamente para os dados de 2016 e 2017.

Posteriormente, os dois bancos de dados agregados no nível de docentes (2016 e 2017) foram mesclados (comando merge files) em um único banco, tomando os códigos identificadores únicos

4 O cálculo da taxa de rotatividade para anos posteriores a 2017 não é possível a partir dos microdados disponibilizados na página do Inep em face do cumprimento da Lei de Acesso à Informação (2011). Sob justificativa de proteção de dados e informações pessoais dos docentes, a partir de 2018, o Inep passou a atribuir códigos identificadores individuais diferentes a cada levantamento anual. Assim, estudos que requeiram análises longitudinais dos docentes em diferentes anos do Censo Escolar ficam condicionados a um processo de consulta presencial, em Brasília-DF, ao Serviço de Acesso a Dados Protegidos (Sedap) do Inep, conforme Portaria n. 52/2019.

5 Jannuzzi (2005) apresenta uma lista de 12 propriedades desejáveis para os indicadores sociais.

6 Nas sinopses estatísticas referentes ao número de docentes, o Inep não inclui auxiliares da educação infantil, docentes de turmas de atividade complementar e docentes de Atendimento Educacional Especializado (AEE).

7 Utilizando o dicionário de variáveis dos microdados do Censo Escolar 2016, esses filtros foram operacionalizados da seguinte forma: 'tp_tipo_docente' = 1 ou 5 e 'tp_tipo_turma' = 0, 1, 2 ou 3. 
atribuídos pelo Inep aos professores e às escolas (variáveis "co_pessoa_fisica" e "co_entidade") nessa ordem como variáveis-chave. ${ }^{8}$ O banco de 2016 foi tomado como ano-base. Assim, a variável "ano" com o conteúdo "2016" foi renomeada como "ano_base". Com base na mescla, esse banco de dados obteve nova variável denominada "ano_comparacao". A nova variável continha duas possibilidades de conteúdo: "2017", nos casos em que o código do docente que estava na escola em 2016 fosse encontrado no banco de dados de 2017; ou o valor "zero", caso não fosse encontrado o código do docente na mesma escola em 2017.

Tal organização permitiu, na sequência, o cálculo da variável "rotatividade docente”. Com base na definição de rotatividade como saída, para cada docente foi realizada a seguinte operação:

(a) Se "ano_base" = "2016" \& "ano_comparacao" = 0, então rotatividade = "sim";

(b) Se "ano_base" = "2016” \& “ano_comparacao" = "2017”, então rotatividade = "não”.

O resultado desse procedimento indicava a incidência ou não de rotatividade por docente para o ano de 2017. O resultado dos procedimentos até esse ponto permitiu a análise da rotatividade no nível dos docentes, conforme apresentada nas tabelas 2 e 3 na seção de resultados.

Em seguida, por meio de novo processo de agregação do banco de dados de docentes pela variável "co_escola”, foi gerado um outro banco de dados com o número total de professores em 2016 e o número de saídas em 2017 por escola. A fórmula proposta neste artigo foi aplicada ao banco de dados com números agregados por escola para obtenção da taxa de rotatividade docente por escola. A taxa no nível das escolas subsidiou os resultados apresentados nas tabelas 4, 5, 6 e no Gráfico 1 na seção de resultados.

\section{Apresentação de resultados}

Os resultados foram apresentados utilizando análise estatística descritiva. Por não se tratar de estudo amostral, não foram realizados testes estatísticos inferenciais.

$\mathrm{Na}$ tentativa de identificar fatores explicativos para a incidência da rotatividade docente no município de Curitiba-PR, a taxa de rotatividade foi apresentada em perspectiva com algumas variáveis descritoras das características, condições e contexto de trabalho dos docentes. Nas análises no nível dos docentes, foram utilizadas as variáveis "dependência administrativa, "vínculo empregatício" e "etapa de ensino" (tabelas 2 e 3, na seção seguinte). Nas análises no nível das escolas, foram consideradas as variáveis "dependência administrativa", "tipo de unidade escolar", "distância do marco zero da cidade", "política de difícil provimento" e "percentual de gratificação". As quatro últimas variáveis são específicas da rede municipal de Curitiba-PR e foram obtidas por meio de levantamento documental em normas internas da Secretaria Municipal de Educação (tabelas 4, 5 e 6 e Gráfico 1 na seção de resultados).

Por fim, considerando a importância da análise das políticas públicas e dos fenômenos sociais e organizacionais ao longo do tempo, foi calculada a taxa de rotatividade das escolas municipais em uma série histórica de cinco anos (2013 a 2017). O intuito foi verificar se o indicador proposto possui atributos metodológicos importantes para análises que consideram a variável "tempo", quais sejam: "sensibilidade às ações previstas" e "comparabilidade da série histórica” (Jannuzzi, 2005). Veja Gráfico 1 na seção de resultados.

8 Para a realização desse procedimento, é fundamental que os códigos identificadores únicos das escolas e dos docentes sejam os mesmos nas edições do Censo Escolar que forem utilizadas. 


\section{Resultados e discussão}

Esta seção apresenta os resultados que visam a responder às questões atinentes ao nível de rotatividade docente nas escolas de educação básica, à magnitude do fenômeno entre as escolas das redes públicas e da esfera privada e, ainda, à discussão de alguns fatores explicativos. A Tabela 2 apresenta as taxas de rotatividade por dependência administrativa pública e por tipo de mantenedor privado para o munícipio de Curitiba-PR. Apesar da unidade de análise da pesquisa remeter à escola, os resultados dessa tabela mostram valores no nível dos docentes a fim de permitirem a análise da magnitude do fenômeno em relação ao tamanho do quadro de cada esfera analisada.

\section{TABELA 2}

TAXA DE ROTATIVIDADE DOCENTE POR DEPENDÊNCIA ADMINISTRATIVA E TIPO DE MANTENEDOR PRIVADO, CURITIBA-PR, 2017 (ANÁLISE DO NÍVEL DOS DOCENTES)

\begin{tabular}{|c|c|c|c|}
\hline $\begin{array}{l}\text { Dependência } \\
\text { administrativa }\end{array}$ & Número de docentes em 2016 & $\begin{array}{l}\text { Número de docentes que } \\
\text { saíram em } 2017 \text { das escolas } \\
\text { que trabalharam em } 2016\end{array}$ & Taxa de rotatividade 2017 \\
\hline Federal & 379 & 46 & $12,1 \%$ \\
\hline Estadual & 8.811 & 4.697 & $53,3 \%$ \\
\hline Municipal & 10.400 & 2.457 & $23,6 \%$ \\
\hline Privada conveniada & 1.352 & 447 & $33,1 \%$ \\
\hline $\begin{array}{l}\text { Privada comunitária, } \\
\text { confessional ou filantrópica }\end{array}$ & 976 & 227 & $23,3 \%$ \\
\hline Privada c/ fins lucrativos & 6.548 & 1.919 & $29,3 \%$ \\
\hline Total & 28.466 & 9.793 & $34,4 \%$ \\
\hline
\end{tabular}

Fonte: Elaboração dos autores, com base nos microdados do Censo Escolar (Inep, 2017, 2018).

De acordo com a Tabela 2, a taxa de rotatividade docente na cidade de Curitiba, em 2017, foi de 34,4\%. Essa taxa se aproxima da rotatividade da mão de obra geral do Brasil $(35,3 \%)$ encontrada pelo MTE (MTE, 2013) e daquela obtida pelo Dieese (2014a) para a rotatividade dos profissionais do ensino (31,5\%). Ainda que o contexto e o trabalho sobre os quais incide e os efeitos e as formas de medição do fenômeno sejam distintos, salvaguardados os devidos distanciamentos, tal comparação permite situar os resultados encontrados em um cenário mais amplo.

A estratificação por dependência administrativa evidencia que o fenômeno recai com maior incidência entre os docentes da rede pública estadual de ensino (53,3\%). A rede municipal, que possui o maior quadro docente entre as categorias analisadas (36,5\% do total), tem rotatividade significativamente menor (23,6\%). A rede federal apresenta a menor taxa observada em 2017 (12,1\%). As categorias de escolas privadas têm um quadro docente de tamanho bastante distinto. As escolas com fins lucrativos empregam $23 \%$ da força de trabalho docente da cidade e apresentaram rotatividade de $29,3 \%$. As instituições conveniadas apresentaram rotatividade docente da ordem de 33,1\%. A título de síntese, ao somar o número de docentes em 2016 e de saídas em 2017, verificou-se que: as escolas públicas têm rotatividade conjunta de $36,7 \%$; e as escolas privadas, de $29,2 \%$. A maior taxa entre as escolas públicas é claramente influenciada pela rede estadual, que possui grande parte do quadro composto por docentes com contratos temporários (Tabela 3). De toda forma, os achados em Curitiba denotam uma diferença da pesquisa de Ingersoll (2001) sobre o contexto norte-americano, no qual a esfera privada apresentou taxas de rotatividade mais elevadas. A taxa geral apresentada pelo autor $(13,2 \%)$ também foi bem menor. 
Mirando especificamente a dependência municipal, verifica-se uma proximidade com a taxa alcançada no estudo de Cunha (2015) para a rede municipal de ensino do Rio de Janeiro (de 20 a 30\%).

Mantendo a mesma unidade de análise, a Tabela 3 apresenta um aprofundamento dos achados com desagregações da taxa de rotatividade por tipo de vínculo empregatício e etapa/modalidade de ensino nas quais atuam os professores.

Embora o tipo de vínculo concursado/estável/efetivo seja predominante na rede pública de Curitiba $(82,4 \%)$, a rede estadual de ensino apresenta quase $40 \%$ do seu quadro em caráter temporário. Essa modalidade de contratação, por meio de Processo Seletivo Simplificado (PSS), implica saídas periódicas, voluntárias e involuntárias desses docentes das escolas estaduais. Não por acaso, a taxa de rotatividade entre os temporários é bastante elevada (83,3\%). Além disso, o contrato temporário produz relações de trabalho distintas daquelas dos profissionais estatutários com os quais esses docentes atuam de modo concomitante. Se, conforme apontado anteriormente, a consciência profissional do servidor estatutário está vinculada ao reconhecimento de obrigações decorrentes de um estatuto profissional, por outro lado, os contratos sujeitam tal consciência profissional a uma lógica de obediência ao empregador (Supiot, 1995). Esses contratos submetem ainda o trabalho à lógica de mercado, modificando as relações de poder, remuneração e tempo destinado ao trabalho, no sentido da continuidade da função (Supiot, 1995).

O reconhecimento dessa forte dualidade entre tipo de vínculo e suas consequências, inclusive sobre o trabalho coletivo para materialização de um projeto educativo comum e a necessidade de coesão da equipe no interior das escolas, instiga a pensar sobre o fato de que a taxa entre os docentes estáveis da rede estadual $(34,8 \%)$ continua sendo a mais elevada entre as redes públicas de ensino em Curitiba. 


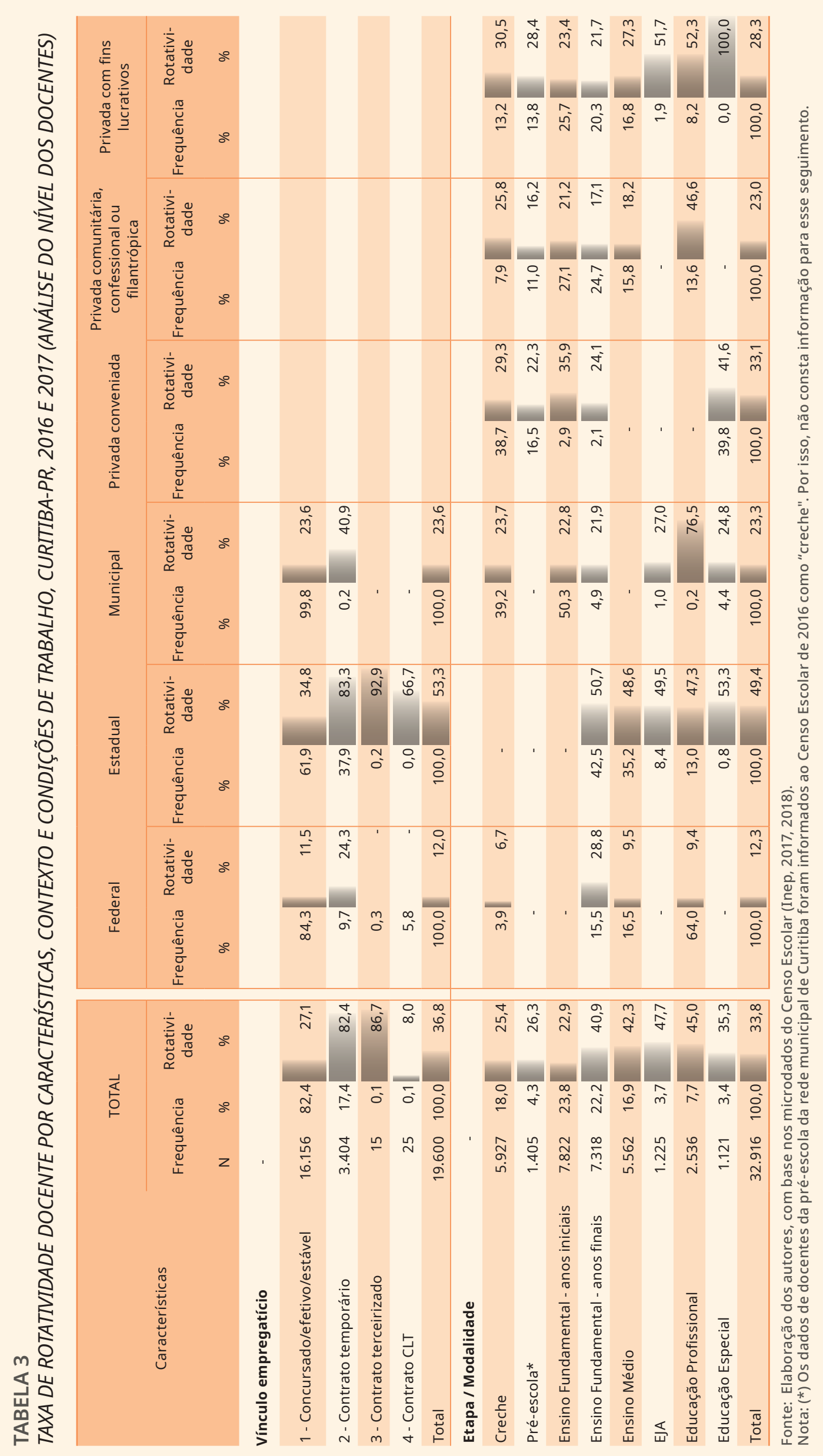


Tal achado é coerente aos resultados obtidos por Medeiros et al. (2010) e Linhares, (2014), os quais expressam relação entre a rotatividade profissional no âmbito público e a precarização dos vínculos empregatícios. Também Sancho et al. (2011) explicitam a relação entre instabilidade de contratos e incidência de rotatividade, observando-a em níveis mais elevados quando relacionada a vínculos empregatícios não estatutários na administração pública.

Quanto à rotatividade dos docentes das diferentes etapas/modalidades de ensino, a Tabela 3 mostra que, no agregado do quadro docente do município (sem distinção de dependência administrativa e categoria de escola privada), a taxa varia de 22,9\% (ensino fundamental - anos iniciais) a $47,7 \%$ (educação de jovens e adultos - EJA). Os números mostram que essa variação é fortemente influenciada pelo contexto das redes de ensino e categorias de escolas privadas. Os docentes que atuam no segmento creche, por exemplo, têm rotatividade de 6,7\% nas escolas federais, $23,7 \%$ nos CMEIs da rede municipal e 30,5\% nas escolas com fins lucrativos. Os dados revelam grande discrepância na rotatividade dos docentes dos anos iniciais $(22,9 \%)$ e finais do ensino fundamental (40,9\%). Isso se deve à divisão de responsabilidade pela oferta desses segmentos de etapa no estado do Paraná entre as escolas municipais e estaduais. A oferta pública dos anos finais é responsabilidade da rede estadual, e nessa rede a rotatividade é de $50,7 \%$. Aliás, a taxa de rotatividade é superior a $40 \%$ em todas as etapas/modalidades cuja oferta é majoritariamente mantida pela rede estadual (ensino médio $=48,6 \%$ e EJA $=49,6 \%$ ). Vale notar que a educação profissional tem rotatividade geral de $45 \%$. Todavia, é nessa modalidade que atua maior número dos professores das escolas federais e, nessa rede, a rotatividade é de 9,4\%. Nas escolas estaduais, a rotatividade é de 47,3\%; nas comunitárias, confessionais e filantrópicas é de 46,6\%; e, nas escolas lucrativas, chega a 52,3\%. Na educação especial, a taxa geral é de $35,3 \%$. Nessa modalidade atuam 39,8\% dos docentes das instituições conveniadas e nelas a rotatividade é de 41,6\%.

No entanto, como anteriormente mencionado, a compreensão mais ampla da rotatividade docente requer observá-la à luz da correlação de forças organizacionais que concorrem para sua produção. Assim, as investigações que seguem tomam a escola como unidade de análise. A Tabela 4 apresenta um conjunto de medidas descritivas da taxa de rotatividade docente por escola para cada categoria considerada na análise.

TABELA 4

TAXA DE ROTATIVIDADE DOCENTE POR DEPENDÊNCIA ADMINISTRATIVA E TIPO DE MANTENEDOR PRIVADO, CURITIBA-PR, 2017 (ANÁLISE DO NÍVEL DAS ESCOLAS)

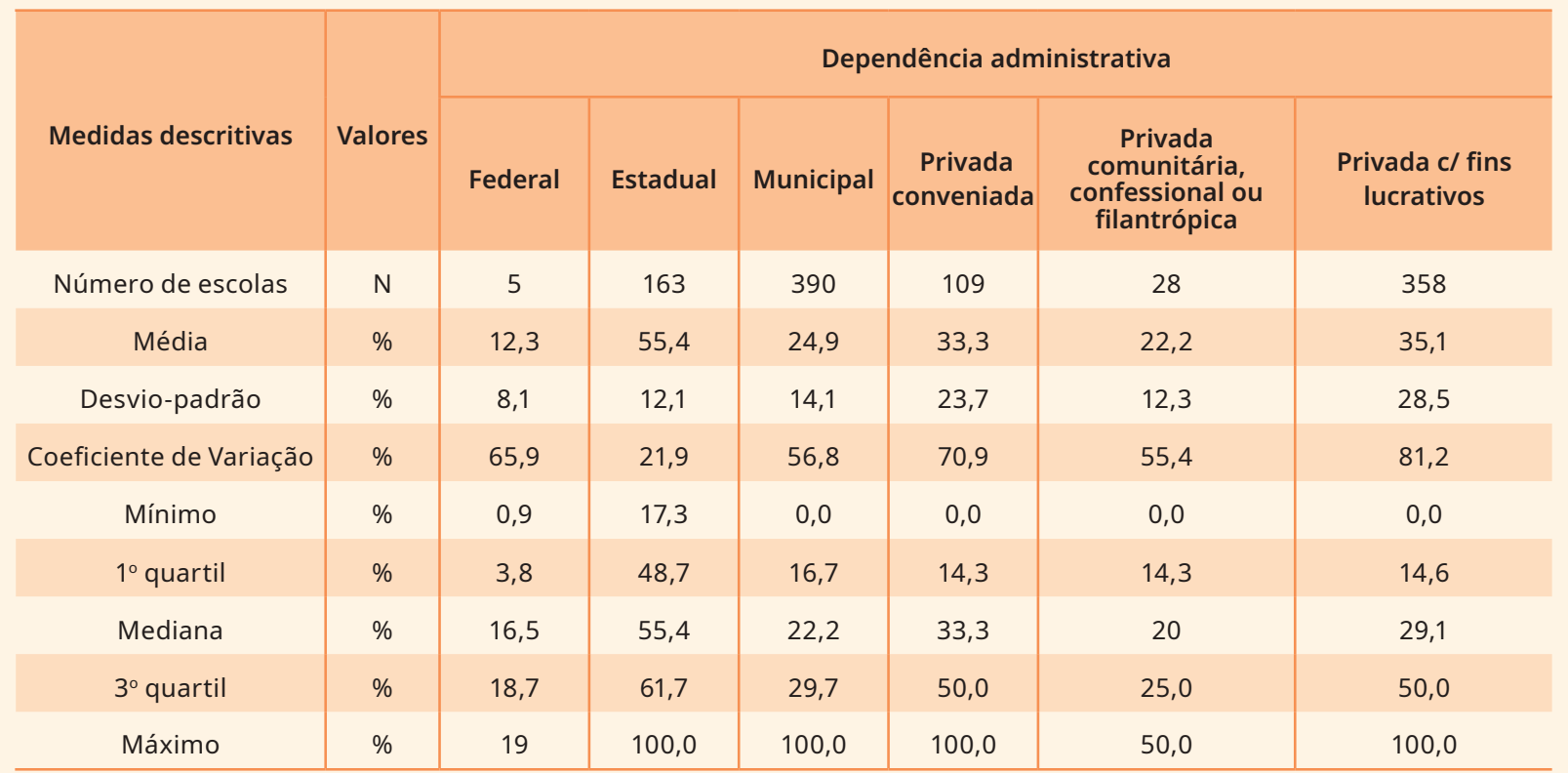

Fonte: Elaboração dos autores, com base nos microdados do Censo Escolar (Inep, 2017, 2018). 
Os dados mostram que a rotatividade é mais elevada nas 163 escolas estaduais sediadas em Curitiba. Em 2017, essas escolas tinham rotatividade média de 55,4\%. Aproximadamente $75 \%$ das escolas têm taxas maiores do que $48,7 \%$ (valor do $1^{\circ}$ quartil). É também nessa rede que o fenômeno incide de forma mais homogênea (coeficiente de variação - $\mathrm{CV}=21,9 \%$ ). Por outro lado, as menores taxas foram verificadas nas cinco escolas federais do município (12,3\%). Nessas escolas, a amplitude da taxa oscilou entre $0,9 \%$ e $19 \%$. A rede municipal tem um número de unidades bem maior do que as demais redes públicas da cidade (390), e a rotatividade média foi de $24,9 \%$ no ano analisado. Embora haja expressiva heterogeneidade na distribuição dos valores $(\mathrm{CV}=56,8 \%)$, é importante considerar que a rotatividade nessa rede tem valores significativamente menores do que na rede estadual e nas escolas privadas (conveniadas e com fins lucrativos). Aproximadamente $75 \%$ das escolas municipais apresentaram rotatividade de até $29,7 \%$ (valores do $3^{\circ}$ quartil).

Quantoaosetor privado,osdadosda Tabela4mostram queas trêscategoriasanalisadas possuem características distintas, a começar pelo número de escolas. Vale ressaltar que, no ano analisado, esse setor empregou $31,2 \%$ dos professores e ofertou 34,2\% das matrículas da educação básica de Curitiba ( $27,2 \%$ das matrículas em escolas com fins lucrativos). Em 2017, a rotatividade incidiu em magnitude semelhante entre as escolasconveniadas e com finslucrativos (médiade $33,1 \%$ e $35,1 \%$, respectivamente). A expressiva incidência também é evidenciada por taxas de rotatividade superiores a $50 \%$ em pelo menos $25 \%$ dessas escolas (vide valores do $3^{\circ}$ quartil). Por outro lado, relevando a heterogeneidade dessas escolas, é possível notar escolas sem incidência de rotatividade e pelo menos $25 \%$ delas com taxas inferiores a $15 \%$. Por fim, os nú meros revelam que o melhor desempenho quanto à rotatividade docente no setor privado está entre as escolas comunitárias, confessionais e filantrópicas (não conveniadas). A média das 28 escolas dessa categoria é de $22,2 \%$ e aproximadamente $75 \%$ dessas escolas têm taxas de rotatividade de até $25 \%$.

Os dados apresentados na Tabela 4 diferem dos resultados de Pereira e Oliveira (2016) para o cenário nacional, que identificam a dependência administrativa municipal como a esfera pública que apresenta o maior valor mediano e as taxas de rotatividade docente mais dispersas.

Ademais, a atribuição de sentido às taxas obtidas carece de uma aproximação mais estreita com os elementos da realidade pontual, a fim de ampliar o espectro de compreensão do fenômeno, visando a adensar potencial explicativo sobre a sua incidência no âmbito público de ensino. Por isso, optou-se, nesta pesquisa, pela definição da Rede Municipal de Ensino de Curitiba como universo de investigação explicativa.

É necessário considerar que a rede municipal de Curitiba é composta por dois tipos de unidade de ensino: Centro Municipal de Educação Infantil (CMEI) e escolas. Em termos de oferta, os CMEIs compreendem as matrículas exclusivamente na educação infantil (sobretudo de creche), enquanto as escolas podem ofertar pré-escola e ensino fundamental (predominantemente anos iniciais). Os docentes que atuam nessas unidades, embora tenham o concurso público de provas e títulos como critério de ingresso comum, situam-se em meio a uma dualidade histórica que os segmenta em duas carreiras distintas: uma denominada "profissional do magistério" e outra, mais recente, denominada "professor da Educação Infantil”. Ainda que a carreira de "professor da Educação Infantil” atribua a este o status profissional de docente não previsto para a carreira anterior de "educador", essa dualidade mantém a ausência de isonomia nas condições de trabalho entre docentes de uma mesma rede de ensino, culminando na distinção, não apenas da exigência de formação mínima para ingresso e local de trabalho, mas também entre planos de carreira, jornada semanal de trabalho, tempo destinado à hora-atividade e remuneração. As principais diferenças entre essas carreiras encontram-se expressas no Quadro 2. 


\begin{tabular}{|c|c|c|}
\hline \multirow[b]{2}{*}{ Condições de trabalho docente } & \multicolumn{2}{|c|}{ Carreira } \\
\hline & $\begin{array}{l}\text { Professor da Educação } \\
\text { Infantil }\end{array}$ & Profissional do magistério \\
\hline Plano de carreira vigente em $2016^{[1]}$ & Lei n. 14.580/2014 & Lei n. 14.544/2014 \\
\hline Local de trabalho & CMEI & CMEI e escola \\
\hline Formação mínima exigida para ingresso na carreira & $\begin{array}{l}\text { Ensino Médio - Modalidade } \\
\text { Magistério }\end{array}$ & $\begin{array}{l}\text { Ensino Superior em } \\
\quad \text { licenciatura }\end{array}$ \\
\hline Jornada de trabalho semanal & 40 horas & 20 horas \\
\hline Vencimento inicial da carreira & $\mathrm{R} \$ 2.360 .82$ & $\mathrm{R} \$ 2.065 .46$ \\
\hline $\begin{array}{c}\text { Percentual de hora-atividade sobre a jornada semanal de } \\
\text { trabalho em atenção à Lei n. } 11.738 / 2008\end{array}$ & $20 \%$ & $33 \%$ \\
\hline
\end{tabular}

Fonte: Elaboração dos autores, com base na Lei Municipal n. 14.580 (2014) e na Lei Municipal n. 14.544 (2014).

Nota: [1] Cabe destacar que ambos os planos de carreira, vigentes até 2017, encontram-se suspensos por força da Lei Municipal n. 15.043 (2017) cujo escopo estende a suspensão a todos os planos de carreira do serviço público municipal de Curitiba.

À vista disso, parece necessário olhar para a incidência de rotatividade desagregada por tipo de unidade. Com base na Tabela 5, pode-se concluir que, em 2017, os CMEIs apresentaram taxa média de rotatividade e dispersão mais elevadas do que as escolas.

Além disso, os valores para CMEI a partir do $3^{\circ}$ quartil superam a incidência obtida entre as escolas, atingindo o valor máximo de $100 \%$, enquanto o limite das escolas não ultrapassa $72 \%$.

\section{TABELA 5}

TAXA DE ROTATIVIDADE DOCENTE POR TIPO DE UNIDADE ESCOLAR, REDE MUNICIPAL DE CURITIBA, 2017 (ANÁLISE DO NÍVEL DAS ESCOLAS)

\begin{tabular}{|c|c|c|c|}
\hline Medidas descritivas & valores & CMEI & ESCOLA \\
\hline Número de estabelecimentos & N & 205 & 185 \\
Média & $\%$ & 25,4 & 24,3 \\
\hline Desvio-padrão & $\%$ & 16,7 & 10,7 \\
\hline Coeficiente de Variação & $\%$ & 65,6 & 0,0 \\
\hline Mínimo & $\%$ & 0,0 & 18,1 \\
\hline 1'quartil & $\%$ & 15,6 & 22,6 \\
\hline Mediana & $\%$ & 21,1 & 29,3 \\
\hline
\end{tabular}

Fonte: Elaboração dos autores, com base nos microdados do Censo Escolar (Inep, 2017, 2018).

O Gráfico 1 apresenta uma breve série histórica, a fim de situar tais achados em um recorte temporal mais amplo. A observação da trajetória da rotatividade para cada tipo de unidade de ensino evidencia queda gradual nas taxas de 2013 a 2017, com exceção do ano de 2016. 


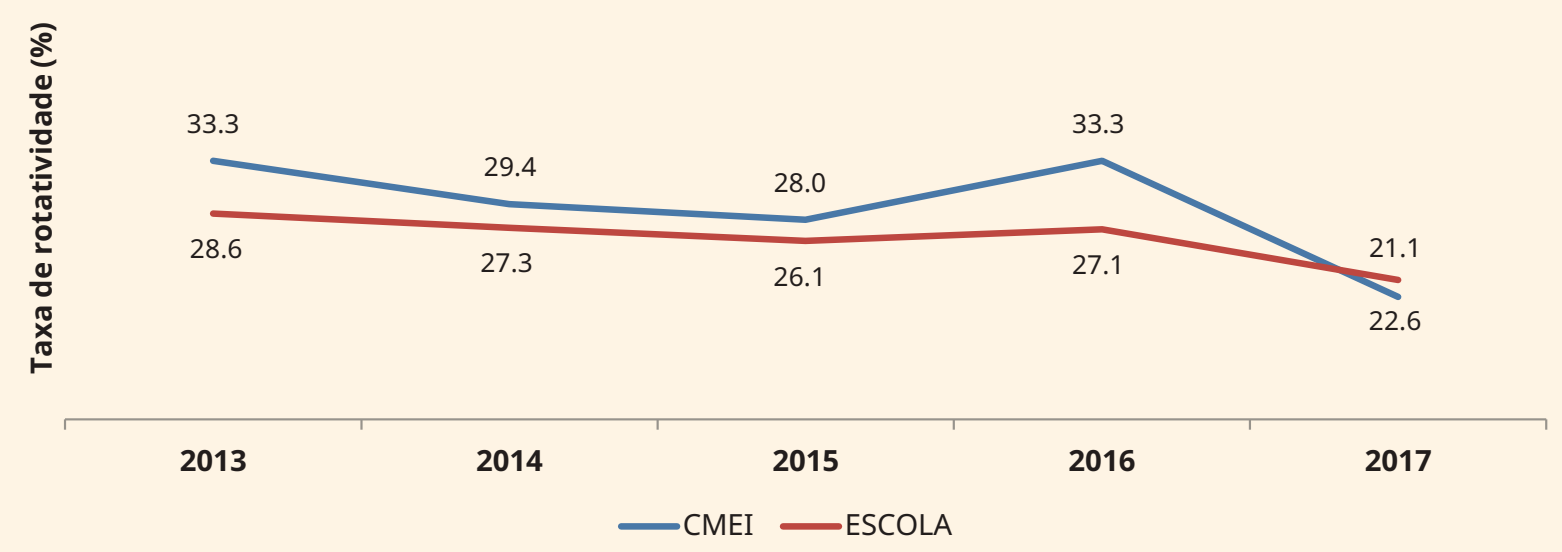

Fonte: Elaboração dos autores, com base nos microdados do Censo Escolar (Inep, 2012, 2013, 2014, 2015, 2016, 2017). Notas: (1) Os docentes registrados como "auxiliar/assistente educacional" nos Censos Escolares de 2013 a 2015 foram incluídos nesta análise, dada sua ocorrência frequente por ocasião da carreira de "educador".

(2) A taxa de rotatividade foi calculada por escola. Os valores apresentados são a mediana da taxa das escolas de cada categoria nos anos analisados.

De modo similar, a análise comparativa entre CMEI e escola permite observar um movimento de progressiva aproximação entres as taxas, novamente à exceção de 2016. No entanto, até 2016 as taxas medianas para os CMEIs foram mais elevadas, chegando a um valor $20 \%$ maior do que aquele obtido para as escolas.

Diante de tais resultados, é possível inferir que as marcas distintivas para as características de cada tipo de unidade de ensino e as condições de trabalho docente, inclusive relacionadas às carreiras dos professores que ali atuam, podem ter algum peso explicativo sobre a incidência da rotatividade docente, uma vez que os achados, em série histórica, revelam sua magnitude mais elevada em CMEI.

Outros fatores que podem ser potencialmente explicativos estão relacionados à distância da escola das regiões mais centrais da cidade e, também, à implantação de uma política de incentivo à permanência na escola mediante gratificação pecuniária aos professores.

Quanto à localização das unidades em relação às áreas mais centrais da cidade, sua objetivação dá-se, na rede municipal de ensino, por uma métrica atribuída a cada escola/CMEI, a qual é utilizada para acúmulo de pontuação do professor para concorrer ao processo anual de remanejamento interno entre as unidades de ensino. Essa medida, denominada valor ponderal (VP), varia de 1 a 8 , sendo 1 atribuído às escolas mais centrais e sua progressão crescente associada ao aumento da distância da unidade em relação ao marco zero da cidade (centro).

Já a política de incentivo à permanência nas escolas, regulamentada em 2001 e efetivada a partir de 2003, foi instituída ante a dificuldade de lotação e alta rotatividade dos quadros profissionais de determinadas unidades de ensino. Tal política prevê, por meio de decreto, a definição das unidades consideradas de difícil provimento, para as quais é previsto o pagamento de gratificação pecuniária percentual a ser recebida pelo servidor enquanto permanecer naquela unidade. Em 2016 as unidades abrangidas pela política representavam cerca de 34\% do total de escolas e CMEIs observados. Essa gratificação, indutora da permanência nessas escolas, varia de 10 a $30 \%$ sobre o vencimento inicial da carreira.

A Tabela 6 apresenta as taxas de rotatividade para essas variáveis. Seus resultados mostram que há uma complexa relação entre taxa de rotatividade e distância, implementação da política de difícil provimento e percentuais de gratificação. 
TABELA 6

TAXA DE ROTATIVIDADE DOCENTE, POR TIPO DE UNIDADE E POR DISTÂNCIA DO MARCO ZERO E \% DE POLÍTICA DE GRATIFICAÇÃO, REDE MUNICIPAL DE CURITIBA, 2017 (ANÁLISE DO NÍVEL DAS ESCOLAS)

\begin{tabular}{|c|c|c|c|c|c|c|}
\hline \multirow[t]{3}{*}{ Aspecto } & \multicolumn{6}{|c|}{ Tipo de unidade de ensino } \\
\hline & \multicolumn{3}{|c|}{ CMEI } & \multicolumn{3}{|c|}{ Escola } \\
\hline & $\mathrm{N}$ & Média (\%) & $\begin{array}{c}\text { desvio- } \\
\text {-padrão (\%) }\end{array}$ & $\mathrm{N}$ & Média (\%) & $\begin{array}{c}\text { desvio- } \\
\text {-padrão (\%) }\end{array}$ \\
\hline Total de unidades de ensino & 205 & 25,4 & 16,7 & 185 & 24,3 & 10,7 \\
\hline \multicolumn{7}{|c|}{ Distância do marco zero da cidade (VP) } \\
\hline 1 & 2 & 22,7 & 10,3 & 2 & 32,4 & 7,2 \\
\hline 2 & 10 & 32,6 & 24,5 & 17 & 29,7 & 11,9 \\
\hline 3 & 25 & 22,9 & 13,9 & 37 & 23,6 & 11,1 \\
\hline 4 & 62 & 22,7 & 14,8 & 42 & 22,4 & 11,0 \\
\hline 5 & 47 & 28,3 & 18,3 & 40 & 25,0 & 10,4 \\
\hline 6 & 30 & 23,9 & 13,0 & 22 & 24,7 & 9,9 \\
\hline 7 & 12 & 23,6 & 19,2 & 10 & 22,6 & 11,8 \\
\hline 8 & 17 & 31,0 & 20,6 & 15 & 22,9 & 7,7 \\
\hline \multicolumn{7}{|c|}{ Política de difícil provimento implementada } \\
\hline Não & 137 & 27,8 & 19,0 & 122 & 25,1 & 11,6 \\
\hline $\operatorname{sim}$ & 68 & 20,6 & 9,1 & 63 & 22,9 & 8,6 \\
\hline \multicolumn{7}{|c|}{ Percentual de gratificação - permanência na escola } \\
\hline 0 & 137 & 27,8 & 19,0 & 122 & 25,1 & 11,6 \\
\hline $10 \%$ & 28 & 22,0 & 9,0 & 25 & 23,2 & 8,2 \\
\hline $20 \%$ & 23 & 17,2 & 7,5 & 21 & 22,7 & 10,2 \\
\hline $30 \%$ & 17 & 23,0 & 10,4 & 17 & 22,6 & 7,3 \\
\hline
\end{tabular}

Fonte: Elaboração dos autores, com base em dados coletados em documentos e normatizações emanadas pela SME e microdados do Censo Escolar (Inep, 2017, 2018).

Quanto à distância, é importante destacar que, dentre aquelas unidades de ensino com valores ponderais do 1 ao 3, localizadas em regiões mais centrais da cidade, apenas 7,7\% têm a política de difícil provimento implementada. Esse percentual é de 6,7\% nas unidades do nível 4, 43,7\% no nível 5, 49,1\% no nível 6, 90,9\% no nível 7 e 93,8\% nas unidades mais distantes (nível 8), sendo este último implantado em todas as escolas e em $88,2 \%$ dos CMEIs.

Logo, considerando distância e cobertura da política de difícil provimento, nota-se que a taxa de rotatividade média entre CMEI é menor para as unidades mais centralizadas (22,7\%), atingindo $31 \%$ nas escolas mais distantes (nível 8). Interessante observar que a maior taxa é encontrada no nível 2 $(32,6 \%)$, que alude a localizações mais centrais, com menor cobertura da política, porém inseridas em contextos vulneráveis do ponto de vista socioeconômico e cultural. Um movimento similar é percebido nas escolas mais próximas da região central da cidade, que apresentam maiores taxas (valores ponderais 1 e 2). Taxas inferiores à média são encontradas nas escolas mais distantes, sendo que aquelas sob os valores ponderais 7 e 8 também possuem maior cobertura da política.

Já os resultados para a variável "política implementada" evidenciam que a média é significativamente inferior entre os dois grupos cuja política foi implementada, denotando também menor dispersão interna (CV de 44\% entre os CMEIs e de 37\% entre as escolas).

Quanto aos percentuais de gratificação, percebe-se que as taxas de rotatividade entre as escolas apresentam-se menores à medida que o percentual aumenta, o que expressa que maiores percentuais de gratificação podem ter relação com a diminuição da incidência do fenômeno. Embora essa não seja uma regularidade comum aos CMEIs, suas taxas para os diferentes percentuais mostram-se inferiores à média geral (24,3\%). 
Ante os resultados obtidos, é possível afirmar que distância, política implementada e percentual de gratificação são fatores intervenientes do nível de rotatividade, mas não guardam uma relação linear. Nesse ponto, vale recordar o estudo de Campos e Malik (2008), que mostra as questóes de distância e de prestígio da instituição como variáveis que explicam parte da incidência de rotatividade profissional no âmbito público.

De toda maneira, a relação dessas variáveis precisa ser problematizada sob a égide das condições de trabalho docente operadas nas unidades consideradas de difícil lotação pela gestão municipal, ante o não preenchimento anual de seus quadros. Tem-se, assim, a política como elemento indutor da atratividade, porém desarticulada da investigação das questões que produzem a dificuldade de lotação de seus quadros.

Em síntese, as análises supracitadas sobre a política em questão - articuladas à constatação de Kasmirski (2012) de que políticas locais de adicional pecuniário agregado à remuneração por local de trabalho demonstram potencial de redução da migração entre escolas - evocam a necessidade de estudos que observem, de forma aprofundada, seus efeitos sobre a incidência da rotatividade docente, tomando como referência o universo de escolas da Rede Municipal de Ensino (RME).

\section{Considerações finais}

Este artigo partiu do pressuposto de que a rotatividade docente na escola, em níveis elevados, pode consistir em obstáculo para o alcance dos objetivos educacionais expressos em um projeto educativo e social. O fenômeno foi pensado à luz da singularidade do trabalho docente, à medida que alude não apenas à saída de um profissional de seu local de trabalho e eventual substituição, mas à ruptura de um fazer político, contínuo, intencional, interativo e coletivo, com vistas à mais ampla formação humana.

No tocante às implicações para as políticas educacionais, tomadas como mediações necessárias à efetivação do direito constitucional à educação, os resultados expressos reiteram a necessidade de revelar, por meio de um indicador, a incidência do fenômeno da rotatividade docente nas escolas de educação básica.

O que se conclui da análise do quadro geral de rotatividade docente em Curitiba, por dependência administrativa e para o conjunto de escolas que a compõe, é que a mensuração do fenômeno explicita uma incidência em patamares elevados. Se a construção teórica empreendida possibilitou marcar seus efeitos negativos sobre a função social da escola e sobre um trabalho de natureza singular, desvelar taxas médias que podem variar de 12,3\% a 55,4\% de incidência, a depender da esfera em que ocorrem, reitera a necessidade de conferir-lhe visibilidade, a fim de ascendê-la como temática pertinente à inserção na agenda política local.

Dentre os limites da pesquisa, é importante salientar que, embora se reconheça a possibilidade de relação entre rotatividade e formas diferenciadas de gestão escolar, uma vez que essa relação tensiona, em graus distintos, o trabalho docente e as relações de poder inerentes à escola, essa é uma dimensão não observada neste estudo. Também não foi aferida a relação entre os pares, a qual pode ser explicativa do interesse em sair ou permanecer em uma escola.

Há que se destacar a possibilidade de replicação do indicador para outros contextos brasileiros, uma vez que foi elaborado a partir de uma base de dados disponibilizada anualmente pelo Inep. Isso abre possibilidades infindáveis de diagnósticos, análises e discussão. Assim, podem ser pautados como agenda de trabalhos futuros: a) esforços que busquem identificar fatores organizacionais que concorrem para a produção da rotatividade, como condição à tomada de decisão política que vise à sua redução; b) estudos que captem as especificidades que geram a acentuada dessemelhança na incidência do fenômeno entre CMEIs e escolas; c) análises explicativas com um conjunto amplo de variáveis independentes e modelagem estatística mais sofisticada; d) análises de séries históricas do indicador para conhecer a trajetória de incidência do fenômeno visando, entre outros resultados, à construção de parâmetros "toleráveis" de rotatividade docente nas escolas de educação básica. 


\section{Referências}

Azevedo, K. A. A. (2012). Rotatividade docente e suas implicações no contexto escolar. Secretaria de Estado de Educação. http://www.diaadiaeducacao.pr.gov.br/portals/cadernospde/pdebusca/producoes_ pde/2010/2010_uel_ped_artigo_kelly_aparecida_almeida_azevedo.pdf

Campos, C. V. de A., \& Malik, A. M. (2008). Satisfação no trabalho e rotatividade dos médicos do Programa de Saúde da Família. Revista de Administração Pública, 42(2), 347-368.

Constituição da República Federativa do Brasil de 1988. (1988). Senado Federal. https://www2.senado.leg.br/ bdsf/bitstream/handle/id/518231/CF88_Livro_EC91_2016.pdf

Cunha, M. B. (2015). Rotatividade docente na Rede Municipal de Ensino da cidade do Rio de Janeiro [Tese de Doutorado, Pontifícia Universidade Católica do Rio de Janeiro]. Biblioteca Digital Brasileira de Teses e Dissertações. http://bdtd.ibict.br/vufind/Record/PUC_RIO-1_a8562aefffaf012e546b66ecd9fbbfc8

Decreto n. 23.020 de 17 de junho de 2003. (2003). Dispõe sobre a gratificação pelo exercício de atividades em unidades escolares situadas em local de difícil acesso. Prefeitura Municipal do Rio de Janeiro.

Decreto n. 235 de 27 de março de 2007. (2007). Estabelece os requisitos para o recebimento da gratificação prevista nos parágrafos $1^{\circ}, 2^{\circ}, 3^{\circ}$ e $4^{\circ}$, do artigo 34 , da Lei n. $12.083 / 2006$ e artigos $1^{\circ}$, $2^{\circ}$ e $3^{\circ}$ da Lei n. 12.114/2007. Câmara Municipal de Curitiba.

Departamento Intersindical de Estatística e Estudos Socioeconômicos. (2014a). Os números da rotatividade no Brasil: Um olhar sobre os dados da RAIS 2002-2013. Dieese. https://www.dieese.org.br/ notaaimprensa/2014/numerosRotatividadeBrasil.pdf

Departamento Intersindical de Estatística e Estudos Socioeconômicos. (2014b). Rotatividade e as pesquisas públicas para o mercado de trabalho. Dieese. https://www.dieese.org.br/livro/2014/livroRotatividade.pdf

Diógenes, L. C., Paschoal, T., Neiva, E. R., \& Meneses, P. P. M. (2016). Intenção de rotatividade e percepção de suporte organizacional em um órgão público federal. Revista do Serviço Público, 67(2), 147-172. https://doi.org/10.21874/rsp.v67i2.655

Duarte, R. G. (2009). Os determinantes da rotatividade dos professores no Brasil: Uma análise com base nos dados do SAEB 2003 [Dissertação de mestrado, Universidade de São Paulo]. Biblioteca Digital de Teses e Dissertações da USP. https://doi.org/10.11606/D.96.2009.tde-07052010-163617

Fanfani, E. T. (2005). La condición docente: Analisis comparado de la Argentina, Brasil, Perú y Uruguay. Siglo XXI Editores. https://unesdoc.unesco.org/ark:/48223/pf0000144319/PDF/144319spa.pdf.multi

Frantz, M. G. (2018). Rotatividade docente nas escolas públicas de Educação Básica: Marcas da singularidade do fenômeno [Dissertação de Mestrado, Universidade Federal do Paraná]. Repositório Digital Institucional da UFPR. https://hdl.handle.net/1884/58638

Grissom, J. A. (2011). Can good principals keep teachers in disadvantaged schools? Linking principal effectiveness to teacher satisfaction and turnover in hard-to-staff environments. Teachers College Record, 113(11), 2552-2585.

Ingersoll, R. (2001). Teacher turnover and teacher shortages: An organizational analysis. American Educational Research Journal, 38(3), 499-534.

Instituto Nacional de Estudos e Pesquisas Educacionais Anísio Teixeira. (2017). Microdados do Censo Escolar da Educação Básica 2016. Inep. http://portal.inep.gov.br/artigo//asset_publisher/B4AQV9zFY7Bv/ content/microdados-do-censo-escolar-2016-ja-podem-ser-consultados/21206

Instituto Nacional de Estudos e Pesquisas Educacionais Anísio Teixeira. (2018). Microdados do Censo Escolar da Educação Básica 2017. Inep. http://portal.inep.gov.br/artigo/-/asset_publisher/B4AQV9zFY7Bv/ content/microdados-do-sistema-de-avaliacao-da-educacao-basica-de-2017-sao-divulgados/21206

Jannuzzi, P. de M. (2005). Indicadores para diagnóstico, monitoramento e avaliação de programas sociais no Brasil. Revista do Serviço Público, 56(2), 137-160. https://doi.org/10.21874/rsp.v56i2.222

Johnson, S. M., Berg, J. H., \& Donaldson, M. L. (2005). Who stays in teaching and why: A review of the literature on teacher retention. Project on Next Generation of Teachers, Harvard Graduate School of Education. 
Kasmirski,P.R.(2012).Mobilidade deprofessores na redeestadualpaulista [Dissertação de mestrado, Universidade de São Paulo]. Biblioteca Digital de Teses e Dissertações da USP. https://doi.org/10.11606/D.12.2012. tde-20022013-163802

Lei n. 9.394, de 20 de dezembro de 1996. (1996). Estabelece as Diretrizes e Bases da Educação Nacional. MEC.

Lei n. 10.190 de 28 de junho de 2001. (2001). Institui o plano de carreira do magistério público municipal, alterando as leis n. 8.580/94, 6.761/85 e 8.579/94. Câmara Municipal de Curitiba.

Lei n. 11.738, de 16 de julho de 2008. (2008). Regulamenta a alínea "e" do inciso III do caput do art. 60 do Ato das Disposições Constitucionais Transitórias, para instituir o piso salarial profissional nacional para os profissionais do magistério público da educação básica. Diário Oficial da União.

Lei n. 14.544, de 11 de novembro de 2014. (2014). Instituiu o Plano de Carreira do Profissional do Magistério de Curitiba. Câmara Municipal de Curitiba.

Lei n. 14.580, de 22 de dezembro de 2014. (2014). Reestrutura a carreira dos profissionais da educação infantil da Prefeitura Municipal de Curitiba. Câmara Municipal de Curitiba.

Lei n. 15.043 de 2017. (2017). Altera a data de pagamento do terço de férias dos servidores para o mês de férias dos trabalhadores. Câmara Municipal de Curitiba.

Linhares, L. M. (2014). Rotatividade no serviço público: Estudo de caso do cargo de analista de planejamento e orçamento [Dissertação de mestrado, Universidade de Brasília]. Repositório Institucional da UnB. https://repositorio.unb.br/handle/10482/36884

Medeiros, C. R. G., Junqueira, Á. G. W., Schwingel, G., Carreno, I., Jungles, L. A. P., \& Saldanha, O. M. de F. L. (2010). A rotatividade de enfermeiros e médicos: Um impasse na implementação da Estratégia de Saúde da Família. Ciência \& Saúde Coletiva, 15(suppl 1), 1521-1531. https://doi.org/10.1590/S141381232010000700064

Ministério do Trabalho e do Emprego. (2013). Avaliação Financeira do Fundo de Amparo ao Trabalhador - FAT. (Nota Técnica n. 043/2013/CGFAT/SPOA/SE/MTE). Secretaria Executiva. http://www.planalto. gov.br/ccivil_03/Projetos/PLN/2013/Anexos/MSG153-IV.9\%20Abono\%20e\%20Seguro\%20 Desemprego.pdf

Nomura, F. H., \& Gaidzinski, R. R. (2005). Rotatividade da equipe de enfermagem: Estudo em hospital-escola. Revista Latino-Americana de Enfermagem, 13(5), 648-653. https://doi.org/10.1590/s010411692005000500007

Paranaíba, N. F. (2014). Satisfação no trabalho e intenção de rotatividade de servidores das carreiras de uma autarquia federal. In M. R. de S. Camões, D. R. da F. Fonseca, \& V. Porto (Eds.), Estudos de gestão de pessoas no serviço público (Cadernos ENAP, 37, pp. 119-142). ENAP.

Pereira, E. A., Jr. (2017). Condiçôes de trabalho docente nas escolas de educação básica no Brasil: Uma análise quantitativa [Tese de Doutorado, Universidade Federal de Minas Gerais]. Repositório Institucional Universidade Federal de Minas Gerais. https://repositorio.ufmg.br/handle/1843/BUOS-AQQPSG

Pereira, E. A., Jr., \& Oliveira, D. A. (2016). Indicadores de retenção e rotatividade dos docentes da educação básica. Cadernos de Pesquisa, 46(160), 312-332. https://doi.org/10.1590/198053143370

Sancho, L. G., Carmo, J. M. do, Sancho, R. G., \& Bahia, L. (2011). Rotatividade na força de trabalho da rede municipal de saúde de Belo Horizonte, Minas Gerais: Um estudo de caso. Trabalho, Educação e Saúde, 9(3), 431-447.

Silva, J. L. (2007). A rotatividade docente numa escola da rede estadual de ensino [Dissertação de mestrado, Pontifícia Universidade Católica de São Paulo]. TEDE: Sistema de Publicação Eletrônica de Teses e Dissertações. https://tede2.pucsp.br/handle/handle/10610

Silva, M. R. da. (2011). Perspectivas curriculares contemporâneas. Ibpex.

Siqueira, W. R. de, \& Alves, L. C. F. (2016). Rotatividade de professores universitários: O caso de um campus fora da sede. Revista de Administração, Contabilidade e Economia da Fundace, 7(2). https://doi. org/10.13059/racef.v7i2.324 
Supiot, A. (1995). A crise de espírito do serviço público. Adverso - Revista da Associação de Docentes da UFRGS, $5(7), 16-25$.

Tardif, M., \& Lessard, C. (2014). O trabalho docente: Elementos para uma teoria da docência como profissão de interações humanas. Vozes.

Torres, R. V. B. S. (2015). Rotatividade no poder executivo federal: Uma análise das intençōes de sair e de permanecer dos servidores comissionados [Dissertação de mestrado, Universidade de Brasília]. Repositório Institucional da UnB. https://repositorio.unb.br/handle/10482/18361

Vicentini, P. P., \& Lugli, R. G. (2009). História da profissão docente no Brasil: Representaçöes em disputa. Cortez.

Weber, M. (1994). Os três tipos de dominação legítima. In M. Weber (Ed.), Economia e sociedade. Editora UnB.

\section{Nota sobre autoria}

Maíra Gallotti Frantz: delineamento do estudo; revisão da literatura; método, análise de dados e resultados. Thiago Alves: delineamento do estudo; método, análise de dados e resultados.

\section{Disponibilidade de dados}

Os dados desta pesquisa estão disponíveis em: https://data.scielo.org/dataverse/brcp

\section{Como citar este artigo}

Frantz, M. G., \& Alves, T. (2021). Proposta de um indicador de rotatividade docente na educação básica. Cadernos de Pesquisa, 51, Artigo e07211. https://doi.org/10.1590/198053147211 